\title{
Estimates \& Implications of Obsessive Compulsive Personality Disorder (OCPD) Prevalence: OCPD as a Common Disorder with a Cosmopolitan Distribution or Rare Strategy with a Northerly Distribution?
}

\section{Estimaciones e Implicaciones de la Prevalencia del Trastorno Obsesivo- Compulsivo: ¿Trastorno habitual con una distribución cosmopolita o estrategia infrecuente con una distribución septentrional?}

\author{
Steven C. Hertler \\ Department of Psychology, College of New Rochelle, New Rochelle, New York, USA \\ Disponible online 30 de abril de 2015
}

\begin{abstract}
DSM-V estimates the prevalence of Obsessive Compulsive Personality Disorder (OCPD) to fall between 2.1 and 7.9 percent, making it one of the most prevalent personality disorders in the general population. Yet, obsessive prevalence is reported without its significance being appreciated. After reviewing the estimates of several studies, this paper pursues the theme of obsessive prevalence, showing why it was ignored, how it changes etiological assumptions, and, in turn, how newly generated etiologies engender the understanding of obsessive prevalence. High prevalence, when paired with high heritability, undermines psychoanalytic etiologies and invalidates psychiatric classification, suggesting that OCPD is a rare type, rather than a common disorder. Following this, evolutionary theory is used to illustrate the conditions from which this rare phenotype arose, and the mechanistic laws that maintain it within its present proportions. As treated within the discussion section, high prevalence, when contextualized within an evolutionary explanatory paradigm, suggests an ecologically determined biogeography of OCPD.
\end{abstract}

Key Words: Obsessive Compulsive Personality Disorder; Prevalence; Epidemiology; Evolution; Negative Frequency dependent Balancing Selection; Heritability.

El DSM-V estima que la prevalencia del trastorno obsesivo-compulsivo oscila entre el 2,1 y el 7,9 por ciento, lo que lo convierte en uno de los trastornos de personalidad de mayor prevalencia en la población general. Sin embargo, la prevalencia del trastorno se suele publicar sin valorar las implicaciones de este hecho. Tras la revisión de las estimaciones que aparecen en varios estudios, este artículo analiza por qué se ha ignorado la prevalencia de este trastorno, cómo cambia este hecho los supuestos etiológicos y el modo en que las nuevas etiologías propuestas ayudan a comprender la prevalencia del trastorno obsesivo-compulsivo. La elevada prevalencia unida a la alta heredabilidad ponen en tela de juicio la etiología psicoanalítica e invalidan la clasificación psiquiátrica, y además sugieren que el trastorno obsesivo-compulsivo no es común, sino infrecuente. Siguiendo esta línea argumental, se utiliza la teoría evolucionista para ilustrar las condiciones bajo las que surge este fenotipo infrecuente y las leyes mecanicistas que lo mantienen en sus actuales proporciones. Tal y como se plantea en la discusión, cuando la elevada prevalencia del trastorno obsesivo-compulsivo se contextualiza dentro de un paradigma evolucionista, aflora la existencia de una biogeografía ecológicamente determinada de este trastorno.

Palabras Clave: Trastorno de personalidad obsesivo-compulsivo; Prevalencia; Epidemiología; Evolución; Selección equilibrada dependiente de la frecuencia negativa; Heredabilidad.

Correspondence concerning this article should be addressed to: Steven C. Hertler. 115 Pine Street, Ridgewood, NJ 07450 USA. Phone: (862) 2109043. E-mail: stevenhertler@hotmail.com 


\section{The Prevalence of Obsessive Compulsive Personality Disorder}

The personality pattern of rigidity, sedulousness, conscientious laboring, anxious tension, parsimoniousness, insular selfreliance, and perfectionism that was initially described as "Anal Character", has been thereafter labeled by the World Health Organization's International Classification of Diseases (ICD) as "Anankastic Personality" and the American Psychiatric Association's Diagnostic and Statistical Manual of Mental Disorders (DSM) as "Compulsive Personality", "Obsessive-Compulsive Personality", "Compulsive Personality Disorder" and "Obsessive Compulsive Personality Disorder” (Pfohl \& Blum, 1991). This latter term, Obsessive Compulsive Personality Disorder (OCPD), is the most recent variant used in the fifth edition of the DSM, and it is the acronym OCPD or simply the word obsessive that will be used herein as this personality disorder's prevalence is reported and its significance considered.

Using a massive sample comprised of 2,794 participants, Reichborn-Kjennerud and colleagues (2007) found that 69 persons, or 2.5 percent, identified as having OCPD features. Citing several sources (Demal, et al., 1993; Kozak \& Foa, 1994; Swedo et al., 1989; Thomsen \& Jensen, 1994), Hollander (1997) places OCPD prevalence between 11 and 14 percent. Referencing more than six separate research groups, Hummelen et al. (2008) estimates that the prevalence of OCPD ranges from 5.1 to 16.4 percent. Looking individually at Hummelen et al's. (2008) referenced studies reveals differences in sampling, measurement, inclusion and tolerance of comorbidity that might partially account for the wide range of prevalence.

Estimating OCPD prevalence at 16.4 percent, Hyler, Kellman, Oldham \& Skodol (1992) collected a small sample of 100 "chronically and severely disabled patients" who were then diagnosed, with 290 personality disorders using the Structured Clinical Interview for DSM Disorders (SCID-II), and 249 personality disorders using the Personality Disorder Examination (PDE). Hyler et al. (1992) apparently fail to discuss the presence of Axis I disorder comorbidity which might contribute to the sample's being so clinically impaired and needing inpatient care. On the other hand, they do speak extensively of the excessive Axis II comorbidity denoted by each participant having between 2.49 and 2.90 personality disorder diagnoses, which it seems they view partially as a natural corollary of the continuous nature of personality and its disorders. Likewise, though using a sample five times as large, Zanarini et al. (1998) also culled their sample from a group of inpatients using structured interview. Upon admission, all subjects were screened and deemed to more probably present with personality pathology than a serious organic condition, such as schizophrenia. Focusing on Borderline Personality Disorder, Zanarini et al's. (1998) study also shows significant comorbidity with many participants receiving two or more diagnoses. While reporting a 10.4 percent prevalence for OCPD, Zanarini et al. (1998) also note that twenty percent of their sample was diagnosed with Bor- derline Personality Disorder, despite the paradoxical fact that Borderline Personality Disorder is characterized by impulsivity and erratic behavior, whereas Obsessive Compulsive Personality Disorder is characterized by compulsivity and behavioral overcontrol.

Also using structured interviewing, though not using professional psychiatrists or psychologists as interviewers, Grant et al. (2004) conducted a study distinguished by its outsized sample of 43,093 accessed through interviews conducted as part of the National Epidemiological Survey on Alcohol and Related Conditions. At a rate of 7.9 percent, OCPD was the most prevalent personality disorder in Grant et al's. (2004) sample, which surveyed noninstitutionalized Americans at military bases, boarding homes, nontransient hotels, shelters, group homes and college housing. As recognized and grappled with by the authors, here again is a sample rife with comorbidity. OCPD specifically was consistently associated with all other PDs [personality disorders] with the exceptions of Antisocial Personality Disorder. As Grant et al. (2004) end their article with a discussion of comorbidity, so Stuart et al. (1998) begin their article on this very same score. Also, like Grant et al. (2004), Stuart et al. (1998) employ a large sample; precisely, a sample of 1116 participants that amalgamates smaller samples from Italy, Iowa, Dallas, and Minneapolis, which variously include inpatients, outpatients and non-patients without excluding those with various Axis I disorders. Akin to the study by Hyler et al. (1992), Stuart et al. (1998), after eliminating nearly half the sample because they did not have a diagnosable personality disorder, diagnosed the remainder with an average of 2.7 personality disorders per participant. Of the 183 participants diagnosed with OCPD, only 29 were exclusively diagnosed with OCPD. So Stuart et al. (1998) report approximately 16 percent OCPD prevalence, though this drops dramatically to approximately 3 percent if comorbid diagnoses are excluded. In yet another study, Zimmerman, Rothschild and Chelminski (2005) sampled 859 outpatients using structured clinical interview, of which 270 were diagnosed with a personality disorder, and 75 , or 8.7 percent, were specifically diagnosed with OCPD. As in other studies referenced above, those within Zimmerman et al's. (2005) who were diagnosed with a personality disorder, were most often diagnosed with two or more. Likewise, using structured interview, Fossati et al. (2000) studied 431 consecutively admitted psychiatric patients; a sample showing comorbidity rates greater than 50 percent. Most significantly, though this latter sample was similar in sampling methods, inclusion criteria, and rates of comorbidity, it found a relatively low prevalence rate of 5.1 percent.

When turning to the Diagnostic and Statistical Manual of Mental Disorders (DSM), one finds some variability also. DSM-IV-TR reports one of the most conservative prevalence rates, finding Obsessive Compulsive Personality Disorder to be present in only one percent of community samples (American Psychiatric Association, 2000). However, DSM-V estimates 
the prevalence of Obsessive Compulsive Personality Disorder to be between 2.1 and 7.9 percent (American Psychiatric Association, 2013).

There are several issues that confound any attempt to procure accurate prevalence rates, and which contribute to variation within and between samples. Firstly, variation in operational definitions produces variation in prevalence: Are researchers sampling obsessive traits or obsessive style, versus some more formal description, such as Obsessive Compulsive Personality Disorder as strictly specified by the DSM? Secondly, variation in measurement will produce variation in prevalence: Are researchers using scales from a personality inventory, chart review or structured interview? Thirdly, variation in culture will produce variation in prevalence: Does a given society esteem or pathologize the traits across which obsessives are extreme? (Alarcón \& Foulks, 1995; Leising, Rogers \& Ostner, 2009) Finally, variation in sampling technique will produce variation in prevalence: Are researchers, for instance, using non-patient, out-patient or in-patient populations? Thus, prevalence estimates are plagued by methodological problems that produce frustratingly broad estimates. Nevertheless, by making reasonable inferences one can still hone in on a narrower estimate of obsessive numbers: Upper extremes could potentially arise from researchers administering the NEO-PI-R, or some like measure of normal personality trait variation, to convenience samples of college students, and conflating elevations in conscientiousness with the compulsive conscientiousness characteristic of OCPD. However, from the studies just reviewed, it seems that all the instances of prevalence rates exceeding ten percent were obtained from moderately large samples of psychiatric inpatients (Hyler et al., 1992; Stuart et al., 1998; Zanarini et al., 1998). Excessive comorbidity is characteristic of all such studies, as illustrated best by Stuart et al.'s (1998) sample wherein OCPD prevalence is reduced more than fivefold when controlling for the multiply-diagnosed. Additionally, these functionally compromised inpatient participants were, in some instances, liable to present with a comorbid axis I disorder. So, in attempting to apprehend general population prevalence by way of extrapolation from these psychiatric samples, threats to internal validity arise from rampant comorbidity, and threats to external validity arise from non-random sampling.

At the same time, lower extremes are probably inaccurate as well. DSM-IV-TR's singular estimate of one percent seems, at the very least, statistically improbable. DSM-V provides a more liberal range, again, estimating OCPD to comprise anywhere from 2.1 to 7.9 percent of the population. DSM-V's estimate has the advantage of being based on more data, which is more recent. Also, this latest prevalence estimate is more solidly situated in the middle of the upper and lower extremes that have been reported in research across the years. It certainly eschews the extreme prevalence reported by comorbid, multiply diagnosed inpatients. As such, it seems not unlikely that obsessive prevalence truly falls within this range. In turn, it would not be unreasonable to take the middle of that range: five percent (calculated by averaging 2.1 and 7.9). And yet, conservative as it is, five percent is a rather high number of persons to have a disorder. As judged by the American Psychiatric Association (2013), Obsessive Compulsive Personality Disorder is one of the most prevalent personality disorders in the general population.

\section{Purpose and Structure}

The present paper argues that high prevalence, when paired with high heritability, suggests OCPD to be a rare type with a skewed distribution, rather than a common disorder with a cosmopolitan distribution. This paper pursues the theme of obsessive prevalence, showing why it was ignored, how it generates etiological support for an evolutionary etiology, and, in turn, by what means that evolutionary etiology makes predictions about the prevalence and distribution of obsessive persons. More specifically, support for this thesis proceeds by way of the following structure: First, expanding upon previous work (Hertler, 2014a), the paradox of a disorder being simultaneously common, harmful, and heritable, as articulated by Keller and Miller (2006), is treated abstractly. Thereafter, as it relates to OCPD, the reasons for neglecting to recognize this paradox, and the consequences of failing to face it, are considered. Thirdly, it is shown that while the advent of demonstrably high heritability places OCPD within the purview of the paradox, only psychoanalytic and psychiatric assumptions of pathology retain it there. Following this, empirical evidence of impairment is tempered with evolutionarily relevant evidence of productivity, even as sampling bias and conflation of clinical dysfunction and evolutionary fitness function to obscure this fact. Evidence of commonality and heritability, without evidence of dysfunction, leads to a resolution of Keller and Miller's paradox signifying that OCPD is a product of evolution, the prevalence of which is regulated by negative frequency dependent balancing selection and biogeographically skewed.

\section{The Paradox of Common, Harmful, Heritable Mental Disorders}

As previously reviewed (Hertler, 2014a), Keller and Miller, in 2006, published an article entitled, 'Resolving the Paradox of Common, Harmful, Heritable Mental Disorders.' The paradox, that is the paradox of the existence and perpetuation of mental disorders, only becomes paradoxical when all three conditions, common, harmful, and heritable, are present. If a disorder is merely common and harmful, but not heritable, no paradox exists because the disorder can be gradually insinuated through developmental insult, as is "Fetal Alcohol Syndrome", or abruptly acquired in adulthood, as is "Post-Traumatic Stress Disorder". Alternatively, if a disorder is merely heritable and harmful, but not common, no paradox exists because its presence can be attributed to a deleterious mutation that will soon 
be eliminated from the gene pool. Finally, if a variable is common and heritable, but is not harmful, no paradox exists; this is simply indicative of an individual difference variable such as attached earlobes or dry ear wax. However, from a population genetic perspective, Keller and Miller (2006) are suggesting that those disorders, meeting all three conditions, should not exist and persist. Notwithstanding, it is evident that some psychological disorders, clearly meeting all three conditions, do exist and persist; and so require explanation in a manner that addresses this paradox.

The explanatory burden imposed by the common, harmful, heritable paradox is increasingly being shouldered, with bipolar disorder etiologies serving as an early exemplar. With increased risk of accidental death coming from manic states and an increased risk of suicidal death coming from depressive states, being paired with a heritability estimate of over 0.80 and prevalence that approaches one percent of the general population (Blaney \& Millon, 2009), this is not surprising. The paradoxical persistence of bipolar disorder within the population is most commonly explained by emphasizing concomitant elevations in creativity (Jamison, 1995; Keller \& Miller 2006; Mackali, Gülöksüz \& Oral, 2014). In this way, high mortality is negated by high fecundity. Dying young from suicide might be counterbalanced via the increased mate value conferred by the artistic temperament. As such, Bipolar Disorder would be a case of "antagonistic pleiotropy" as specified by Williams (Kirkwood \& Rose, 1991), in which a single gene creates a phenotype that has both positive and negative consequences that counterbalance one another (Penke, Denissen \& Miller, 2007). Somewhat differently, there is the possibility that creativity is present, not necessarily or exclusively among those with bipolar disorder, but among their relatives (Andreasen, 1987; Shapiro \& Weisberg, 1999; Simeonova, Chang, Strong \& Ketter, 2005). In this instance, the latent genetics of bipolar disorder give rise to creativity, and it is creativity which is selected for. This continues the family lineage, bringing along with it creativity and mental illness together. As such, Bipolar Disorder would be a case of "heterozygote advantage" as specified by Fisher (1931), in which recessive genes prove advantageous, while fully expressed dominant genes prove disadvantageous. In this way, the positive and negative consequences of bipolar disorder are counterbalanced, not within the individual as in antagonistic pleiotropy, but within the lineage (Penke, Denissen \& Miller, 2007). Finally, other bipolar etiologies emphasize the correlation between bipolar disorder and a pyknic, coldadapted build, suggesting a relationship between mood, light (Golden et al., 2005) and circadian rhythm (Yin, et al., 2006) imposed by long winters and short summers (Sherman, 2012). It is not presently pertinent to judge which theory best explains how bipolar disorder can be simultaneously common, harmful and heritable; rather it is only important to emphasize that each places Keller and Miller's (2006) paradox in the center of their explanatory endeavor.
Failing to Recognize and Resolve the Paradox

For most of its history, OCPD did not face Keller and Miller's (2006) paradox, not only because it was not yet articulated, but because it was assumed to be quite common and largely harmful, but not sufficiently heritable. Notwithstanding historical assumptions, OCPD is heritable; highly so. It is now fourteen years since Torgersen et al. (2000) published data suggesting that OCPD was nearly as heritable as Bipolar Disorder; though this data remains dissociated from etiological accounts. Yet, evidence of heritability can not be ignored in perpetuity. And, high heritability, when paired with commonness and harmfulness, produces profound implications: A disorder, any disorder, whether heritable or not, should reduce the fitness and fecundity of the person in which it resides. As previously detailed (Hertler, 2014a), if a very common condition like obsessive character (American Psychiatric Association, 2013) is primarily acquired postnatally, this depression in fecundity hardly matters, as new dysfunctional crops of obsessives can be made in each generation by poor parenting in the manner specified by psychoanalysts. Alternatively, however, if this same common condition is primarily inherited, as we now know OCPD to be, this depression in fecundity matters greatly. The heritable disorder, the underlying genotype that produces that disorder, and the people who carry that genotype, all together should dwindle as they fail to replicate themselves at the mean reproductive rate (Keller, 2008). In this way, with the knowledge that OCPD is particularly strongly influenced by genes (Torgersen et al., 2000), its prevalence is converted from an inconsequential statistic to an inexplicable impasse for psychoanalytic etiologies and psychiatric classification (Hertler, 2014a).

If etiological theorists studying bipolar disorder feel it incumbent upon them to assume the burden of the common, heritable, harmful paradox, it is all the more important that etiological theorists studying OCPD do so. First, this is a matter of differential prevalence. OCPD characterizes approximately five percent of the population, while bipolar disorder estimates are often placed at, or below, one percent (Judd \& Akiskal, 2003; Lewinsohn, Klein \& Seeley, 1995; Merikangas et al., 2007). The higher the prevalence, the more conspicuous the paradox. As high prevalence makes Keller and Miller's (2006) paradox more germane, so does chronicity of course. Even when an Axis I disorder is chronic, as is bipolar disorder, it is often punctuated by protracted periods of remission. In this way, evolutionarily relevant depression in survival and fecundity occurs only across a portion of the reproductive years. In contrast, an Axis II disorder of personality provides no reprieve and offers no respite. OCPD, like other disorders of personality, is egosyntonic, such that the person cannot separate self and symptoms, remember a time when they were different, or look forward to recovery. Therefore, whatever the evolutionarily relevant depression in fitness and fecundity attached to OCPD, it should operate ceaselessly through the reproductive years. In sum then, as compared to bipolar disorder, it is all the more 
necessary that Obsessive Compulsive Personality Disorder etiologies address the common, harmful, heritable paradox due to increased prevalence and chronicity of course.

\section{Escaping the Paradox: Common and Heritable, but Not Harmful}

As per the standards of Keller and Miller (2006), OCPD is clearly common, even as per the one percent prevalence rate reported by DSM-IV-TR. Given a global population of 7,176,023,055 (United States Census Bureau, 2014) even this lowest prevalence estimate suggests that $71,760,230$ persons display this personality organization. Moreover, the persistent identification and classification of OCPD in the hundred years following Freud's original description at least anecdotally suggests that this high prevalence has been sustained intergenerationally. Likewise, there is little reason to doubt the findings of controlled twin studies, which establish OCPD as "particularly strongly influenced by genes" (ReichbornKjennerud et al., 2007; Torgersen, et al., 2000). Confidence in this judgment is derived from its concordance with the more global body of evidence showing that behavioral patterns generally, and traits patterns specifically, are heritable. With parental influence on temperament now known to be negligible (Beer, Arnold \& Loehlin, 1998; Dumont, 2010; Eysenck, 1990; Goldsmith, Buss \& Lemery, 1997; Zuckerman, 1997), and with extra-familial environmental influence on personality often characterized as moderate, it becomes clearer that "up to 70 percent of variance in the major [personality] factors is due to genetic determinants" (Dumont, 2010; p. 125; Hertler 2015a). So, while it is possible that the magnitude of genetic influence on OCPD formation was measured imprecisely, it remains certain, beyond reasonable doubt, that genetic influence is at least as important as environmental influence. Evidence of high heritability and high prevalence, however, only imposes the encumbrance of Keller and Miller's (2006) paradox so long as OCPD is also truly harmful, as supposed by psychoanalytic etiologists and psychiatric diagnosticians. On this score, there is no strong empirical evidence, only long-standing assumptions buttressed by an unsustainable etiological theory.

\section{Empirical Evidence and Obsessive Functionality}

As previously reviewed (Hertler, 2015b) some studies have found evidence of relational problems, especially in marriage (Costa, Samuels, Bagby, Daffin \& Norton, 2005). Likewise, another study found obsessives to be economically expensive, directly in terms of treatment costs, and indirectly in terms of productivity loss (Soeteman, Hakkaart-van Roijen, Verheul \& Busschbach, 2008). Furthermore, in those presenting with a diagnosed axis I disorder, OCPD can augment symptoms and retard recovery. Finally, suicidal ideation and behavior are increased among depressive individuals with comorbid obsessive traits (Diaconu \& Turecki, 2009).
Alternatively, however, Gutiérrez et al. (2013) found that high-C subjects, that is, participants showing general elevations on Cluster C personality disorder traits, of which OCPD is one of three, (1) spent a longer time on studies and in job preparation, (2) displayed higher job stability, (3) attained higher educational and vocational levels (4) more routinely attained positions of status (5) and more easily attained resources. In contrast, high-C subjects were less likely (1) to be arrested, (2) obtain illegal income, (3) abuse drugs, or (4) engage in violent aggression. Moreover, it should be noted that these participants were selected from a sample of treatment seeking outpatients, some of which were retained in spite of mild to moderate comorbid Axis I disorders. Additionally, these findings are reported amidst a general failure to find fitness relevant depression, such as attenuated reproduction and survival, for select Cluster B and Cluster C personality disorders. So after making clear that Gutiérrez et al. (2013) are generally arguing that certain personality disorders might be strategies rather than as diseases or defects, it is important to consider previously presented (Hertler, 2015b) data, which collectively show that OCPD is perhaps the most functional of all personality disorders; the personality disorder most likely to be a "strategy" and not a "disease or defect": Obsessive Compulsive Personality Disorder was associated with the least overall functional impairment among the personality disorders (Barber et al., 1997; Nakao et al., 1992; Skodol, Gunderson, McGlashan \& Dyck, 2002); OCPD is the least pathological of the personality disorders (Kyrios, Nedeljkovic, Moulding \& Doron, 2007); OCPD is not associated with impaired autonomy or attachment problems as are many personality disorders, such as borderline and avoidant personality (Aaronson, Bender, Skodol \& Gunderson, 2006; Kyrios et al., 2007); OCPD is associated with fewer comorbidities than most other personality disorders (McGlashen et al., 2000); OCPD is not associated with depressed global assessment of function (GAF) (Jovev \& Jackson, 2004). Perhaps most strikingly, obsessive character is predictive of worldly success (Ryder, Costa \& Bagby, 2007; Ullrich, Farrington \& Coid, 2007). Specifically, obsessive personality was found to be positively related to high socio-economic status, good income, and supervisory responsibilities at work, spacious living conditions and home ownership (Ullrich, Farrington \& Coid, 2007).

\section{Contextualizing and Qualifying Evidence of Dysfunction}

Moreover, it must be recognized that much of the abovecited data, whether evincing disorder or functionality, is derived of clinically identified samples actively seeking treatment for acute problems. The research subjects that supply empirical data, and the ailing patients that inform clinical opinion, might very well comprise a small subset of a larger obsessive population. Instead of being randomly selected, obsessive participants are often derived via self-selection of the most severely impaired; and not necessarily the most severely impaired in terms 
of obsessive traits, but the most severely impaired in terms of comorbid axis I conditions, developmental insults, poor attachment and so on. In spite of this, obsessives are routinely commended for their perseverance, industriousness, thriftiness, ambition, and self-control (Villemarette-Pittman et al., 2004), as well as their ability to productively exploit anxious energy (Millon \& Davis, 1996). Few disorders elicit so many caveats. Psychoanalytic accounts, and the psychiatric classification schemes that follow in assuming OCPD to be a pathological personality disorder, do not sufficiently account for the many studies that find preserved functioning and commendable features.

Likewise, it is also necessary to acknowledge the difference between culturally contrived standards of functionality and evolutionary relevant standards of fitness; these are all too easy to conflate (Hertler, 2015b). Empirical demonstrations of dysfunction must translate into depressed fecundity. As established by the work of Gutiérrez et al. (2013), if empirical demonstrations of dysfunction do not depress fecundity, they are only indicative of culturally relativistic judgments, rather than objective evolutionarily based dysfunction (Boudreau, Boswell \& Judge, 2001; Nettle, 2006; Wilson, 1975/2000). For these reasons, however deeply ingrained and long-held, it is most parsimonious to renounce assumptions of pathology, along with the etiological theories on which they rested (Hertler, 2014a; 2015c).

\section{Escaping the Paradox: An Evolutionary Egress}

In spite of precedent, when pressed between assumptions of pathology on one side, and the common, heritable, harmful paradox on the other, pressure is most easily and elegantly relieved by giving over the former so as to escape the latter. In this way, within the present paper, there has been a progression from psychoanalytic understanding of OCPD as common and harmful, to consideration of OCPD as common, harmful and heritable, to recognition of OCPD as common and heritable, but not harmful. Thus, theories of OCPD have progressed from being oblivious to the paradox, to being burdened by it, to being released from it.

With this progression complete, comes the recognition that OCPD is simply common and heritable, but not harmful. Nevertheless, OCPD is extricated from this paradoxical position only at the expense of psychoanalytic etiologies, which then leaves an etiological vacuum. Thus we can say that OCPD is common and heritable, but not harmful, but without knowing why it exists. This vacuum is best filled by an evolutionary etiology capable of explaining the existence and prevalence of OCPD. Previously, OCPD was evolutionarily explained as a non-conditional, heritable behavioral complex, evolving during the Upper Paleolithic and Early Neolithic in response to changing selective pressures that came of northerly migration out of Africa. In this view, OCPD is an adaptation to the predictable hardships imposed by harsh winters, which selected for charac- ter traits such as compulsive conscientiousness, parsimoniousness, future oriented thought and time urgency (Hertler, 2015c). Transitioning from a clement climate rife with unpredictable biotic stressors, to an exacting climate rife with predictable abiotic stressors, made it at once more practicable and more necessary to orient towards, and invest in, the future (Hertler, 2014b). Such an evolutionary etiology, not only explains why OCPD exists, but why it has so long been thought a disorder. Lacking an ecologically informed evolutionary perspective, imbalance was mistaken for dysfunction; substituting relativistic culturally informed standards of balance for objective ecologically informed standards of functionality reveals that obsessive extremes are a response to ecological extremes. Additionally, unlike psychoanalytic etiologies that are contradicted by evidence of heritability, an evolutionary etiology like the one just described, is bolstered by evidence of heritability. Indeed, without a heritable component to obsessive traits, natural and sexual selection could not augment and maintain them. In turn, and most pertinently, under this evolutionary etiology that explains OCPD as a temperamental adaptation instead of a mental disorder, its commonality and persistence within the population becomes evident and expected (Hertler, 2014a).

\section{Explaining Obsessive Prevalence Evolutionarily}

When following psychoanalytic explanation in assuming OCPD to be a disorder, it is relevant to ask why prevalence rates are so high. Alternatively, when following evolutionary explanation in assuming OCPD to be an adaptation to northerly latitudes, it is more relevant to ask why prevalence rates are not higher. In other words, if OCPD is an adaptation to the demands of northerly climates, why aren't all those peoples historically occupying northerly climates obsessive? The answer to this is that other types are also capable of adapting to northern climates using methods other than compulsive labor, parsimony and future oriented thought. To some extent social dominance, collaboration and sharing, cunning and artifice, charisma and leadership, all of which were likely preexisting dispositions prior to migration, remained present. Migration simply created the conditions out of which OCPD could evolve and gain a proportional representation within the population, not the conditions to supplant all other types. As before migration there was a diverse array of competing types, so after migration OCPD was added to those types.

This is consistent with the view that personality diversity is the consequence of intraspecific competition. In vying with one another, humans diverged, developing different personalities that disposed them to different strategies. This differentiation partially relieved competitive pressure. In this way, competition was responsible for generating human personality types, just as it was responsible for creating coherent morphs within many animal species: Bluegill sunfish (Buss \& Greiling, 1999), salmon (Kenrick et al., 2002), fresh water snails (Nettle, 2011), small marine isopods, swordtails (Gross, 1996), cichlid scale- 
eating fish (Stearns \& Hoekstra, 2005), damselflies (Sherrat \& Wilkinson, 2009), dragonflies (Sinervo \& Calsbeek, 2010), guppies (Olendorf et al., 2006), fig wasps (Hardy, Goubault \& Batchelor, 2013), scarabs, dung beetles (Snell-Rood \& Moczek, 2013), Gouldian finches (Pryke et al., 2007), orangutans , and arctic char (Cachel, 2006; Hertler, 2015a). These morphs exhibit different behavioral strategies even as they compete for the same resources. As in the present model, ecological variation can alter the relative success of a particular personality type, as it can alter the relative success of the above-described animal morphs. To the degree that one already subscribes to an evolutionary understanding of personality and individual differences, as consolidated in the work of Buss and Hawley (2011), this explanation of obsessive prevalence will be easy to accept. In such a view there is no ideal personality; rather personality varies as a consequence of "adaptive diversification" (Doebeli, 2011) mechanistically maintained via "balancing selection" (Penke, Denissen \& Miller, 2007).

More specifically, whether speaking of types, morphs, strategies or personalities, adaptive diversity is maintained mechanistically by "negative frequency dependent balancing selection", a process by which fitness wanes as frequency waxes. Even while one strategy might be best, it does not fully outcompete other types because, as it progresses towards fixation within the population, its fitness falls. Adaptive diversity maintained by negative frequency dependent balancing selection might appear abstruse by virtue of its involved nomenclature; though in truth, the concept is actually intuitive and ubiquitous (Hertler, 2015a). In addition to the many morphs described previously, the natural world is rampant with examples of negative frequency dependent balancing selection that render the concept tractable. For instance, crossbill finch populations are evenly divided between beaks that cross right to left, and beaks that cross left to right (Benkman, 1996), just as cichlid scale-eating fish are evenly divided between mouth parts that are right-skewed and mouthparts that are left-skewed (Stearns \& Hoekstra, 2005). Whether preying upon the seeds of a cone or the scales of a fish, rareness results in more nutrition, which, in turn, results in higher fecundity; finally, with higher fecundity of the rare type, it soon ceases to be rare, leading to equilibrium among types. Likewise, negative frequency dependent balancing selection explains relatively balanced sex ratios and parasite-host interactions. Outside of nature, negative frequency dependent balancing selection elucidates, for example, why demand falls when supply rises, and why the revenue of a business declines when more competitors enter the market (Hertler, 2015a).

\section{Rendering Negative Frequency Dependent Balancing Selec- tion Plausible and Compelling}

Negative frequency dependent selection is plausible and compelling only when there is a credible explanation of why each allele's fitness increases as its frequency decreases
(Keller\& Miller, 2006). To construct a truly credible explanation of obsessive prevalence by means of this mechanism, both a primary and a secondary explanation are necessary. The primary explanation arises from competition within the niche: As obsessive numbers begin to wax, compensation begins to wane. Each additional obsessive propels all obsessives towards the point of diminishing returns. If what we now consider compulsive conscientiousness were to become commonplace, the obsessive would not find preferment, for example, in mate selection or employment. Each obsessive would be driven to ever more exacting heights and obtain ever shrinking gains.

The secondary explanation arises from competition among all population members: Obsessives must compete, not only among themselves, but with other strategists and non-strategists. There are numerous niches within the social landscape. Selective pressures will drive segments of the population into each niche. Whether one starts with all obsessives or no obsessives, over time, obsessives would likely come to represent the small stable minority that they presently do. A hypothetical world populated exclusively by obsessives would eventually become pluralistic. In such a world, mutations introducing even subtle amounts of dominance, charisma, or cunning would become extraordinarily successful; and thus they would begin to supplant much of the original obsessive population. Natural and sexual selection would rapidly remunerate such rare mutated population members as they successfully occupied previously vacant niches over many generations (Buss, 1999). Alternatively, in a hypothetical world in which no obsessives were present, mutations conferring obsessive traits would be remunerative and replicated within harsh northerly climates. Eventually, whether waxing because excessively uncommon, or waning because excessively common, OCPD would likely stabilize as a small proportion of the population; perhaps at five percent of that general population. In either scenario, as diversification was remunerated, obsessives would come to co-exist with the dominant, duplicitous and diplomatic. Together, in-group and out-group competition make the obsessive strategy tenable only as a restricted proportion of the population; and perhaps so only in northerly climates.

\section{Discussion}

Recognized as 'the father of epidemiology,' nineteenth century English physician John Snow, eschewing prevailing etiological assumptions, identified the Broad Street pump as the source of a deadly cholera outbreak by mapping the number and location of affected individuals (Salcido, 2013). By scientifically considering prevalence and distribution, Snow was emboldened to abjure the assumption that miasma, vapors or foul air caused cholera. Only in doing so did he identify the contaminated well water located alarmingly close to a cesspit (Salcido, 2013); a signal finding without which Robert Koch could not have later identified cholera contamination as due to a biotic, waterborne bacillus. With the cause now identified, rou- 
tine water testing and microscopic assays can be used to track prevalence of Vibrio cholera. Ever since, the study of disease distribution (Last, 2001) and disease causation (Engelhardt, 1976) has been profitably juxtaposed within the framework of epidemiology.

As is clear specifically in the seminal case of cholera, and generally through the study of epidemiology, etiological assumptions will determine whether existing prevalence rates are thought to be low or high, or thought of at all. With respect to OCPD, for the most part, it seems that prevalence was not thought of at all. It has been reported, rather than investigated. This muted inquisitiveness derives from prevailing psychoanalytic etiological theories, which cast OCPD as a psychogenically acquired disorder arising from various psychosexual and psychosocial stressors perpetrated by parents during development (Gay, 1989; McCann, 2009; Pollak, 1987). Truly, under these assumptions, obsessive prevalence is not a fact to intrigue or inspire investigation. One can assume that since approximately five percent of the population displays obsessive features, five percent of the population was exposed to precipitating developmental dynamics. Yet, by simultaneously considering prevalence and etiology within Keller and Miller's (2006) "common, heritable, harmful paradox", this study is broadly representative of an epidemiological approach to OCPD. Within the present study, obsessive prevalence was used to expose insuperable problems within existing etiologies; then obsessive prevalence was used to justify the use of a more likely alternate etiology; and in turn, that alternate etiology was used to inform the understanding of obsessive prevalence as regulated by negative frequency dependent balancing selection. As detailed below, this process of consecutively using prevalence data and etiological inference can be extended in such a way that may have significant implications for refining the study of obsessive prevalence beyond the present state of knowledge.

\section{Future Research}

Psychoanalytic assumptions of pathology, especially when paired with psychiatric diagnosis of obsessive persons as personality disordered, continue to drive sampling practices, as evidenced by the many outpatient and inpatient participants from which prevalence rates have been derived. This is only natural. Etiological assumptions should inform sampling practices. With the assumption that OCPD is a clinical disorder, it is then logical to sample clinically impaired, treatment-seeking patients. Alternatively, under the present assumption, which suggests OCPD to be an evolved strategy regulated by negative frequency dependent balancing selection, it follows that full knowledge of obsessive prevalence will only come from sampling the general population. With no evidence of evolutionary relevant depression in fitness and fecundity, it is possible that present sampling practices capture only the clinically identified fringe of a larger obsessive population. It may be that the practice of confining most well-funded sampling efforts to the psychiatric interviewing of inpatient samples, which results in the diagnosis of several personality disorders per participant, yields spuriously high prevalence within clinical populations, while obscuring a genuinely high prevalence within the general population. Furthermore, the ecological nature of this evolutionary view suggests that cross national sampling is necessary. Obsessives should be far more prevalent in racial groups that have historically inhabited high latitude climates; for example, populations of Northern European descent should contain far higher obsessive prevalence rates than, for example, populations of Sub-Saharan African descent. So the present model is empirically tractable. Prevalence data can categorically falsify etiological theory. If the previously presented evolutionary model is correct, one should be able to create a biogeography of OCPD...Obsessive character should be most common in those ancestral populations residing between $40^{\circ}$ and $60^{\circ}$ north latitude. These are the world's most acutely seasonal lands, providing the reprieve of summer that can be used to prepare for the demands of winter. So in sum, by virtue of considering what is now known about obsessive prevalence, with what is likely to be true about obsessive origins, cross-national sampling of large sections of the general population should replace focused sampling of psychiatric populations.

\section{References}

1. Aaronson, C. J., Bender, D. S., Skodol, A. E. \& Gunderson, J. G. (2006). Comparison of attachment styles in borderline personality disorder and obsessive compulsive personality disorder. Psychiatric Quarterly, 77, 69-80. http://dx.doi. org/10.1007/s11126-006-7962-x

2. Alarcon, R. D. \& Foulks, E. E. (1995). Personality disorders and culture: Contemporary clinical views (Part A). Cultural Diversity and Mental Health, 1, 3-17. http:// dx.doi.org/10.1037/1099-9809.1.1.3

3. American Psychiatric Association (2000). Diagnostic and statistical manual of mental disorders (4th edition, text revision). Washington, DC: Author. http://dx.doi.org/10.1176/ appi.books.9780890423349

4. American Psychiatric Association (2013). Diagnostic and statistical manual of mental disorders (5th edition). Washington, DC: Author. http://dx.doi.org/10.1176/appi. books.9780890425596.

5. Andreasen, N. C. (1987). Creativity and mental illness. American Journal of Psychiatry, 144, 1288-1292. http:// dx.doi.org/10.1176/ajp.144.10.1288

6. Barber, J. P., Morse, J. Q., Krakauer, I. D., Chittams, J. \& Crits-Christoph, K. (1997). Change in Obsessive-Compulsive and Avoidant Personality Disorders following timelimited supportive-expressive therapy. Psychotherapy, 34, 133-143. http://dx.doi.org/10.1037/h0087774

7. Beer, J. M., Arnold, R. D. \& Loehlin, J. C. (1998). Genetic and environmental influences on MMPI factor scales: Joint model fitting to twin and adoption data. Journal of 
Personality and Social Psychology, 74, 818. http://dx.doi. org/10.1037/0022-3514.74.3.818

8. Benkman, C. W. (1996). Are the ratios of bill crossing morphs in crossbills the result of frequency-dependent selection? Evolutionary Ecology, 10, 119-126. http://dx.doi. org/10.1007/BF01239352

9. Blaney, P. H. \& Millon, T. (2009). Oxford textbook of psychopathology. New York: Oxford University Press.

10. Boudreau, J. W., Boswell, W. R. \& Judge, T. A. (2001). Effects of personality on executive career success in the United States and Europe. Journal of Vocational Behavior, 58, 53-81. http://dx.doi.org/10.1006/jvbe.2000.1755

11. Buss, D. M. (1999). Adaptive individual differences revisited. Journal of Personality, 67, 259-264. http://dx.doi. org/10.1111/1467-6494.00055

12. Buss, D. M. \& Greiling, H. (1999). Adaptive individual differences. Journal of Personality, 67, 209-243. http://dx.doi. org/10.1111/1467-6494.00053

13. Buss, D. M. \& Hawley, P. H. (2011). The evolution of personality and individual differences. New York: Oxford University Press.

14. Cachel, S. (2006). Primate and human evolution. New York: Cambridge University Press.

15. Costa, P., Samuels, J., Bagby, M., Daffin, L. \& Norton, H. (2005). Obsessive-compulsive personality disorder: A review. Personality Disorders, 8, 405. http://dx.doi. org/10.1002/0470090383.ch6

16. Demal, U., Lenz, G., Mayrhofer, A., Zapotoczky, H. G. \& Zitterl, W. (1993). Obsessive-compulsive disorder and depression. Psychopathology, 26, 145-150. http://dx.doi. org $/ 10.1159 / 000284814$

17. Diaconu, G. \& Turecki, G. (2009). Obsessive-Compulsive Personality Disorder and suicidal behavior: Evidence for a positive association in a sample of depressed patients. Journal of Clinical Psychiatry, 70, 1551-1556. http://dx.doi. org/10.4088/JCP.08m04636

18. Dingemanse, N. J. \& Reale, D. (2013). What is the evidence that natural selection maintains variation in animal personalities? In C. Carere \& D. Maestripieri (Eds.), Animal personalities: Behavior, physiology, and evolution (pp. 201220). Chicago, Illinois: University of Chicago Press. http:// dx.doi.org/10.7208/chicago/9780226922065.003.0008

19. Doebeli, M. (2011). Adaptive diversification. Princeton, New Jersey: Princeton University Press. http://dx.doi. org/10.1515/9781400838936

20. Dumont, F. (2010). A history of personality psychology: Theory, science, and research from Hellenism to the twenty-first century. New York: Cambridge University Press. http://dx.doi.org/10.1017/CBO9780511676093

21. Engelhardt, H. T. (1976). Ideology and etiology. Journal of Medicine and Philosophy, 1, 256-268. http://dx.doi. org/10.1093/jmp/1.3.256

22. Eysenck, H. J. (1990). Genetic and environmental contribu- tions to individual differences: The three major dimensions of personality. Journal of Personality, 58, 245-261. http:// dx.doi.org/10.1111/j.1467-6494.1990.tb00915.x

23. Fisher, R. A. (1931). The evolution of dominance. Biological reviews, 6, 345-368. http://dx.doi.org/10.1111/j.1469185X.1931.tb01030.x

24. Fossati, A., Maffei, C., Bagnato, M., Battaglia, M., Donati, D., Donini, M., ... \& Prolo, F. (2000). Patterns of covariation of DSM-IV personality disorders in a mixed psychiatric sample. Comprehensive Psychiatry, 41, 206-215. http:// dx.doi.org/10.1016/S0010-440X(00)90049-X

25. Gay, P. (1989). The Freud reader. New York: Norton \& Company.

26. Golden, R. N., Gaynes, B. N., Ekstrom, R. D., Hamer, R. M., Jacobsen, F. M., Suppes, T., ... \& Nemeroff, C. B. (2005). The efficacy of light therapy in the treatment of mood disorders: a review and meta- analysis of the evidence. American Journal of Psychiatry, 162, 656-662. http://dx.doi.org/10.1176/appi.ajp.162.4.656

27. Goldsmith, H. H., Buss, K. A. \& Lemery, K. S. (1997). Toddler and childhood temperament: expanded content, stronger genetic evidence, new evidence for the importance of environment. Developmental Psychology, 33, 891-905. http://dx.doi.org/10.1037/0012-1649.33.6.891

28. Grant, B. F., Stinson, F. S., Dawson, D. A., Chou, S. P., Ruan, W. J. \& Pickering, R. P. (2004). Co-occurrence of 12-Month Alcohol and Drug Use Disorders and Personality Disorders in the United States: Results From the National Epidemiologic Survey on Alcohol and Related Conditions. Archives of general psychiatry, 61, 361-368. http://dx.doi. org/10.1001/archpsyc.61.4.361

29. Gross, M. R. (1996). Alternative reproductive strategies and tactics: Diversity within sexes. Tree, 11, 92-98. http:// dx.doi.org/10.1016/0169-5347(96)81050-0

30. Gutiérrez F., Gárriz, M., Peri, J. M., Ferraz, L., Sol, D., Navarro, J. B., Barbadilla, A. \& Valdés, M. (2013). Fitness costs and benefits of personality disorder traits. Evolution and Human Behavior, 34, 41-48. http://dx.doi. org/10.1016/j.evolhumbehav.2012.09.001

31. Hardy, I. C. W., Goubault, M. \& Batchelor, T. P. (2013). Hymenopteran contests and agonistic behavior. In I. C. W. Hardy \& M. Briffa (Eds.), Animal contests (pp. 147177). New York: Cambridge University Press. http://dx.doi. org/10.1017/CBO9781139051248.010

32. Hertler, S. C. (2014a). A review and critique of obsessivecompulsive personality disorder etiologies: Reckoning with heritability estimates. Europe's Journal of Psychology, 10, 168-184. http://dx.doi.org/10.5964/ejop.v10i1.679

33. Hertler, S. C. (2014b). The continuum of conscientiousness: The antagonistic interests among obsessive and antisocial personalities. Polish Psychological Bulletin, 45, 5263. http://dx.doi.org/10.2478/ppb-2014-0022

34. Hertler, S. C. (2015a). Crossing the paradigmatic divide in 
personality: Coming to an evolutionary understanding of personality variation. An unpublished manuscript currently in review, Journal of Philosophy and Psychiatry.

35. Hertler, S. C. (2015b). Obsessive personality as an adaptive anachronism: The operation of phylogenetic inertia upon obsessive populations in Western Modernity. Accepted and in press, Psychological Topics.

36. Hertler, S. C. (2015c). Migration load, ecological opportunity, and Obsessive Compulsive Personality Disorder Etiology: Obsessive character as an adaptation to seasonality. Evolutionary Psychological Science, 1, 52-67. http:// dx.doi.org/10.1007/s40806-014-0009-x

37. Hollander, E. (1997). Obsessive-Compulsive disorders: diagnosis, etiology, treatment. Marcel Dekker.

38. Hummelen, B., Wilberg, T., Pedersen, G. \& Karterud, S. (2008). The quality of the DSM-IV Obsessive-Compulsive Personality Disorder construct as a prototype category. Journal of Nervous and Mental Disease, 196, 446-455. http://dx.doi.org/10.1097/NMD.0b013e3181775a4e

39. Hyler, S. E., Kellman, H. D., Oldham, J. M. \& Skodol, A. E. (1992). Diagnosis of DSM-III-R personality disorders by two structured interviews: Patterns of comorbidity. American Journal of Psychiatry, 149, 213-220. http://dx.doi. org/10.1176/ajp.149.2.213

40. Jamison, K. R. (1995). Manic-depressive illness and creativity. Scientific American, 72, 62-62. http://dx.doi.org/10.1038/scientificamerican0295-62

41. Jovev, M. \& Jackson, H. J. (2004). Early maladaptive schemas in personality disordered individuals. Journal of Personality Disorders, 18, 467-478. http://dx.doi.org/10.1521/ pedi.18.5.467.51325

42. Judd, L. L. \& Akiskal, H. S. (2003). The prevalence and disability of bipolar spectrum disorders in the US population: re-analysis of the ECA database taking into account subthreshold cases. Journal of Affective Disorders, 73, 123131. http://dx.doi.org/10.1016/S0165-0327(02)00332-4

43. Keller, M. C. (2008). The evolutionary persistence of genes that increase mental disorders risk. Current Directions in Psychological Science, 17, 395-399. http://dx.doi. org/10.1111/j.1467-8721.2008.00613.x

44. Keller, M. C. \& Miller, G. (2006). Resolving the paradox of common, harmful, heritable mental disorders: Which evolutionary genetic models work best? Behavioral and Brain Sciences, 29, 385-452. http://dx.doi.org/10.1017/ $\underline{\mathrm{S} 0140525 \mathrm{X} 06009095}$

45. Kenrick, D. T., Maner, J. K., Butner, J., Norman, P. L. \& Becker, D. V. (2002). Dynamical evolutionary psychology: Mapping the domains of the new interactionist paradigm. Personality and Social Psychology Review, 6, 347-356. http://dx.doi.org/10.1207/S15327957PSPR0604_09

46. Kirkwood, T. B. \& Rose, M. R. (1991). Evolution of senescence: late survival sacrificed for reproduction. Philosophical Transactions of the Royal Society of London. Series B:
Biological Sciences, 332, 15-24. http://dx.doi.org/10.1098/ rstb.1991.0028

47. Kozak, M. J. \& Foa, E. B. (1994). Obsessions, overvalued ideas, and delusions in Obsessive-Compulsive Disorder. Behaviour Research and Therapy, 32, 343-353. http:// dx.doi.org/10.1016/0005-7967(94)90132-5

48. Kyrios, M., Nedeljkovic, M., Moulding, R. \& Doron, G. (2007). Problems of employees with personality disorders: The exemplar of Obsessive Compulsive Personality Disorder (OCPD). In J. Langan-Fox, C. L. Cooper, \& R. J. Klimoski (Eds.), Research companion to the dysfunctional workplace: Management challenges and symptoms (pp. 4057). Northampton, MA: Edward Elgar Publishing Limited. http://dx.doi.org/10.4337/9781847207081.00010

49. Last, J. M. (Ed.). (2001). A dictionary of epidemiology (Vol. 4). New York: Oxford University Press.

50. Leising, D., Rogers, K. \& Ostner, J. (2009). The undisordered personality: Normative assumptions underlying personality disorder diagnoses. Review of General Psychology, 13, 230-241. http://dx.doi.org/10.1037/a0017139

51. Lewinsohn, P. M., Klein, D. N. \& Seeley, J. R. (1995). Bipolar disorders in a community sample of older adolescents: prevalence, phenomenology, comorbidity, and course. Journal of the American Academy of Child \& Adolescent Psychiatry, 34, 454-463. http://dx.doi.org/10.1097/00004583199504000-00012

52. Mackali, Z., Gülöksüz, S. \& Oral, T. (2014). Creativity and Bipolar Disorder. Turkish Journal of Psychiatry, 25, 1-10.

53. McCann, J. T. (2009). Obsessive-Compulsive and Negativistic Personality Disorders. In P. H. Blaney \& T. Millon (Eds.), Oxford textbook of psychopathology (pp. 671-691). New York: Oxford University Press.

54. McGlashan, T. H., Grilo, C. M., Skodol, A. E., Gunderson, J. G., Shea, M. T., Morey, L. C., Zanarini, M. C. \& Stout, R. L. (2000). The collaborative longitudinal personality disorders study: Baseline axis I/II and II/II diagnostic cooccurrence. Acta Psychiatrica Scandinavica, 102, 256-264. http://dx.doi.org/10.1034/j.1600-0447.2000.102004256.x

55. Merikangas, K. R., Akiskal, H. S., Angst, J., Greenberg, P. E., Hirschfeld, R. M., Petukhova, M. \& Kessler, R. C. (2007). Lifetime and 12-month prevalence of bipolar spectrum disorder in the National Comorbidity Survey replication. Archives of General Psychiatry, 64, 543-552. http:// dx.doi.org/10.1001/archpsyc.64.5.543

56. Millon, T. \& Davis, R. D. (1996). Disorders of personality $D S M-I V$ and beyond. New York: John Wiley \& Sons, Inc.

57. Nakao, K., Gunderson, J. G., Phillips, K. A., Tanaka, N., Yorifuji, K., Takaishi, J. \& Nishimura, T. (1992). Functional impairment in personality disorders. Journal of Personality Disorders, 6, 24-33. http://dx.doi.org/10.1521/ pedi.1992.6.1.24

58. Nettle, D. (2006). The evolution of personality variation in humans and other animals. American Psychologist, 61, 
622-631. http://dx.doi.org/10.1037/0003-066X.61.6.622

59. Nettle, D. (2011). Evolutionary perspectives on the fivefactor model of personality. In D. M. Buss \& P. H. Hawley (Eds.), The evolution of personality and individual differences (pp. 5-28). New York: Oxford University Press.

60. Olendorf, R., Rodd, F. H., Punzalan, D., Houde, A. E., Hurt, C., Reznick, D. N. \& Hughes, K. A. (2006). Frequencydependent survival in natural guppy populations. Nature, 441, 633-636. http://dx.doi.org/10.1038/nature04646

61. Penke, L., Denissen, J. A. \& Miller, G. F. (2007). The evolutionary genetics of personality. European Journal of Personality, 21, 549-587. http://dx.doi.org/10.1002/per.629

62. Pfohl, B. \& Blum, N. (1991). Obsessive-compulsive personality disorder: A review of available data and recommendations for DSM-IV. Journal of Personality Disorders, 5, 363-375. http://dx.doi.org/10.1521/pedi.1991.5.4.363

63. Pollak, J. M. (1987). Obsessive-Compulsive Personality: Theoretical and clinical perspectives and recent research findings. Journal of Personality Disorders, 1, 248-262. http://dx.doi.org/10.1521/pedi.1987.1.3.248

64. Pryke, S. R., Astheimer, L. B., Buttemer, W. A. \& Griffith, S. C. (2007). Frequency-dependent physiological trade-offs between competing colour morphs. Biology Letters, 3, 494497. http://dx.doi.org/10.1098/rsbl.2007.0213

65. Reichborn-Kjennerud, T., Czajkowski, N., Neale, M. C., Orstavik, R. E., Torgersen, S., Tambs, K., Røysamb, E., Harris, J. \& Kendler, K. S. (2007). Genetic and environmental influences on dimensional representations of DSMIV cluster $\mathrm{C}$ personality disorders: A population-based multivariate twin study. Psychological Medicine, 37, 645-653. http://dx.doi.org/10.1017/S0033291706009548

66. Ryder, A. G., Costa, P. T. \& Bagby, R. M. (2007). Evaluation of the SCID-II personality disorder traits for DSM-IV: Coherence, discrimination, relations with general personality traits, and functional impairment. Journal of Personality Disorders, 21, 626-637. http://dx.doi.org/10.1521/ pedi.2007.21.6.626

67. Salcido, R. (2013). The Broad Street Pump: Epidemiology Is More Than Skin Deep. Advances in skin \& wound care, 26, 7. http://dx.doi.org/10.1097/01.ASW.0000425930.08336. c1

68. Shapiro, P. J. \& Weisberg, R. W. (1999). Creativity and bipolar diathesis: Common behavioural and cognitive components. Cognition \& Emotion, 13, 741-762. http://dx.doi. org/10.1080/026999399379069

69. Sherman, J. A. (2012). Evolutionary origin of bipolar disorder-revised: EOBD-R. Medical Hypotheses, 78, 113-122. http://dx.doi.org/10.1016/j.mehy.2011.10.005

70. Sherrat, T. N. \& Wilkinson, D. M. (2009). Big questions in ecology and evolution. New York: Oxford University Press.

71. Simeonova, D. I., Chang, K. D., Strong, C. \& Ketter, T. A. (2005). Creativity in familial bipolar disorder. Journal of Psychiatric Research, 39, 623-631. http://dx.doi. org/10.1016/j.jpsychires.2005.01.005

72. Sinervo, B. \& Calsbeek, R. (2010). Behavioral concepts of selection. In D. Westneat \& C. Fox (Eds.), Evolutionary behavioral ecology (pp. 32-45). New York: Oxford University Press.

73. Skodol, A. E., Gunderson, J. G., McGlashan, T. H. \& Dyck, I. R. (2002). Functional impairment in patients with schizotypal, borderline, avoidant, or obsessive-compulsive personality disorder. The American Journal of Psychiatry, 159, 276-283. http://dx.doi.org/10.1176/appi.ajp.159.2.276

74. Snell-Rood, E. C. \& Moczek, A. P. (2013). Horns and the role of development in the evolution of beetle contests. In I. C. W. Hardy \& M. Briffa (Eds.) Animal contests (pp. 178198). New York: Cambridge University Press. http://dx.doi. org/10.1017/CBO9781139051248.011

75. Soeteman, D. I., Hakkaart-van Roijen, L., Verheul, R. \& Busschbach, J. V. (2008). The economic burden of personality disorders in mental health care. Journal of Clinical Psychiatry, 69, 259-265. http://dx.doi.org/10.4088/JCP. v69n0212

76. Stearns, S. C. \& Hoekstra, R. F. (2005). Evolution: An introduction, 2nd ed. New York: Oxford University Press.

77. Stuart, S., Pfohl, B., Battaglia, M., Bellodi, L., Grove, W. \& Cadoret, R. (1998). The cooccurrence of DSM-III-R personality disorders. Journal of Personality Disorders, 12, 302-315. http://dx.doi.org/10.1521/pedi.1998.12.4.302

78. Swedo, S. E., Rapoport, J. L., Leonard, H., Lenane, M. \& Cheslow, D. (1989). Obsessive-Compulsive Disorder in children and adolescents: clinical phenomenology of 70 consecutive cases. Archives of General Psychiatry, 46, 335-341. http://dx.doi.org/10.1001/archpsyc. 1989.01810040041007

79. Thomsen, P.H. \& Jensen, J. (1994). Obsessive-Compulsive: admision petterns and diagnostic stability. Acta Psychiatrica Scandinavica, 90, 19-24. http://dx.doi. org/10.1111/j.1600-0447.1994.tb01550.x

80. Torgersen, S., Lygren, S., Øien, P. A., Skre, I., Onstad, S., Edvardsen, J., Tambs, K. \& Kringlen, E. (2000). A twin study of personality disorders. Comprehensive Psychiatry, 41, 416-425. http://dx.doi.org/10.1053/comp.2000.16560

81. Ullrich, S., Farrington, D. P. \& Coid, J. W. (2007). Dimensions of DSM-IV personality disorders and life-success. Journal of Personality Disorders, 21, 657-663. http:// dx.doi.org/10.1521/pedi.2007.21.6.657

82. United States Census Bureau. (2014, 10 Thursday). www. census.gov. Retrieved 10, 2, 2014, from United States Census Bureau: http://www.census.gov/population/international/data/worldpop/table population.php

83. Villemarette-Pittman, N. R., Stanford, M. S., Greve, K. W., Houston, R. J. \& Mathias, C. W. (2004). Obsessive Compulsive Personality Disorder and behavioral disinhibition. The Journal of Psychology, 138, 5-22. http://dx.doi. org/10.3200/JRLP.138.1.5-22 
84. Weiss, A. \& Adams, M. J. (2013). Differential behavioral ecology: The structure, life history, and evolution of primate personality. In C. Carere \& D. Maestripieri (Eds.), Animal personalities: Behavior, physiology, and evolution (pp. 96123). Chicago, Illinois: University of Chicago Press. http:// dx.doi.org/10.7208/chicago/9780226922065.003.0005

85. Wilson, E. O. (1975/2000). Sociobiology: The new synthesis: 25th anniversary edition. Cambridge: Harvard University Press.

86. Yin, L., Wang, J., Klein, P. S. \& Lazar, M. A. (2006). Nuclear receptor Rev-erb $\alpha$ is a critical lithium-sensitive component of the circadian clock. Science, 311, 1002-1005. http://dx.doi.org/10.1126/science.1121613

87. Zanarini, M. C., Frankenburg, F. R., Dubo, E. D., Sickel, A. E., Trikha, A., Levin, A. \& Reynolds, V. (1998). Axis II comorbidity of borderline personality disorder. Comprehensive Psychiatry, 39, 296-302. http://dx.doi.org/10.1016/ $\underline{\mathrm{S} 0010-440 \mathrm{X}(98) 90038-4}$
88. Zimmerman, M., Rothschild, L. \& Chelminski, I. (2005). The prevalence of DSM-IV personality disorders in psychiatric outpatients. Prevalence, 162, 1911-1918. http://dx.doi. org/10.1176/appi.ajp.162.10.1911

89. Zuckerman, M. (1997). The psychobiological basis of personality. In H. Nyborg (Ed.) The scientific study of human nature: Tribute to Hans J. Eysenck at eighty (pp. 3-16). Elsevier: Oxford.

Received 8 November 2014

Received in revised form 4 March 2015

Accepted 23 March 2015 